\title{
CLASSIFICATION OF EXPERIMENTAL MOUSE LEPROSY
}

\author{
Yoichiro KAWAGUCHI \\ (The Institute for Infectious Diseases, The University of Tokyo)
}

In 1903, in the first report of murine leprosy, Stefansky described the occurrence of two forms of the disease, glandular and musculo-cutaneous. Since then many investigators have observed natural murine leprosy on the basis of this classification.

With further progress, however, most workers are of the opinion that the glandular and musculo-cutaneous forms are merely early and late stages of the same disease.

The purpose of this experiment is to study in detail the classification of mouse leprosy. As stated in previous reports (La Lepro, 26, 1957), remarkable differences were found between the various inbred strains of mice, when susceptibility to murine leprosy was studied for the purpose of selecting an adequate experimental mouse strain.

This author considered that mouse leprosy should be classified into two polar types, benign and malignant. The skin lesions of the former type, such as of C57BL/6, appeared early and were hard, small and sharply defined, whereas those of the latter type, such as of $\mathrm{C} 3 \mathrm{H}$, developed later, were soft and much larger, with a diffuse thickening appearance.

The variation in susceptibility to murine leprosy, the benign (with resistance) and the malignant (without resistance), is manifested in these two clinical characteristic features.

The course of malignant type is in general progressive, with fatal termination in approximately 30 weeks. On the other hand, the disease may undergo gradual regression and sometimes spontaneous healing in the late stage of the benign type.

Moreover, it is of interest in immunological studies that the administration of BCG to mice, in which the disease occurs as the malignant type, is sometimes possible to convert the malignant type to the benign type.

Taking this fact into consideration, observation with a new classification may contribute to progress in murine leprosy research.

\section{実験鼠癩の病型分類について}

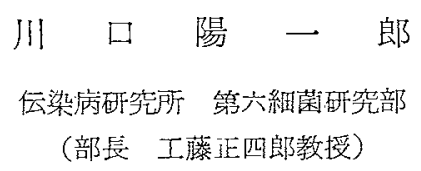

(昭和 34 年 10 月 19 日受稿)

\section{緒言 \\ 园癩における成績から，人癩への類推が可能であると の晃解にもとずき，古くから鼠癩に対する夺防および治}

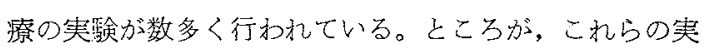
噳成續は研究者によりかなりのくい違いがあり，その意 見を異に与る場合が少くない。こ机法それぞれの用いた 実験方法港ることによるのであるう。特に, 供試動物 
にもとずく成績の羙を䒜視することは岁来まい。そこで

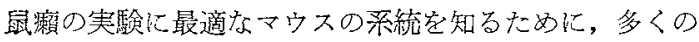
近交系マウスについて種々の実娩を行つてきた。〜8)

この際，国瀬菌をマウスの皮下に接種したところ，接 種部位に生ずる結節の性状は、マウスの系統により，著 しい差のあることが分つた。この点定詳噹に検討する

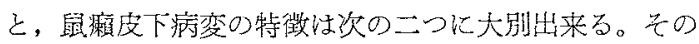
一つ社 $\mathrm{C}_{57} \mathrm{~B} \mathrm{~L} / 6$ 系によつて代表されるものであつて， 結節は早期に触孔ることが出来るが，沃して大きくなら ないものであり，他の一つは $\mathrm{C}_{3} \mathrm{H}$ 系によつて代表され るものであつて，結節老触扎る時期は幄いが，遵には大 結節已なる性質のものである。

鼠癩の病型学この二つの型に分けて考光ると, 予防ま

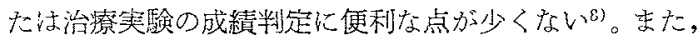
近交糸マウスは，系統により，そ秃ぞれ常に一定の特徵 ある結節在生ずるところから，この病型の発現はマウス の素質とも密接に結びつくものと思秃與味梁い。

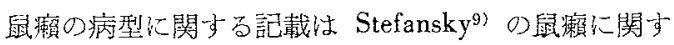
る最初の報告においてすでに兒出されている。すなわ ち, Stefansky は, 自然鼠瀨についての觀祭成縝から,

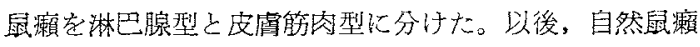
の检索に従事した人々は大体においてこの病型分類を採 用して钼察学行つていたが，これについては疑議定もつ

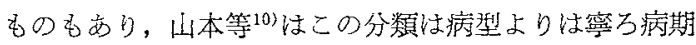

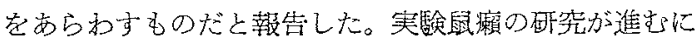
つれて，Stefansky のいう淋巴腺型活軽拝型であり，皮 㲊筋肉型は重症型であると考えら机るようになり，この

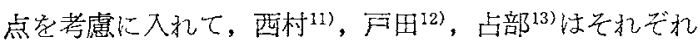
新しい病型分類炎提唱した。

このように，淋世腺のみに病变のあるものを軽症，皮

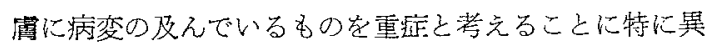
諭はない方，これはあくまで病期或は病樊安示すあので あつて, 病型とはいい難いものと思う。上詎の病型分類 は, 自然鼠㮌検索上の便宜的手段として, 用いられたる ので㐫つて，これには何等䆩主䑁の素質等に関する検討 方行わ玌ていない。

さらに，自然鼠瀨は種々雑多な系統のものを䋩察して いるため湿乱在起し易く，その上，それぞれの病鼠の一 時期の症状学見ているに過ぎない。

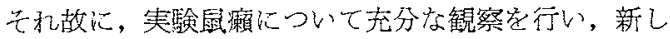
い病型の分類について考察を加えることは鼠瀨矿究の進 步に等与す古所方少くないものと信じ，ここに鼠癞の病 型とマウスの素貿について詇じたいと思う。

\section{鼠癞の病型分類}

鼠攋菌に対する感受性がマウスの柔統によりそれでれ

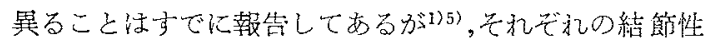
状について，もらすこし詩細にこ杞空検討してみたい。

実験：各系マウスに扩引る鼠癩皮下結简の性状

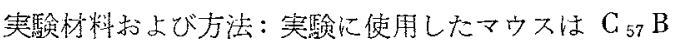
$\mathrm{L} / 6, \mathrm{dba}, \mathrm{NC}, \mathrm{A}, \mathrm{A}_{1}, \mathrm{CFW}, \mathrm{CF}_{1}, \mathrm{BALB} / \mathrm{c}, \mathrm{SM}, \mathrm{C}_{3} \mathrm{H} / \mathrm{He}$, $\mathrm{C}_{3} \mathrm{H}, \mathrm{ddD}$, 以上12禾統の生後約 4 週のものであつて, こ れらはいず机す伝畉獣废䂙究部汃ら入手した。

各系統6品ずつのマウスの前胸部に，鼠獺皮下結節

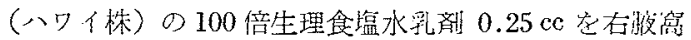
部より皮下接電し，接種後 2 週目ごとに，16週まで，接 種部に生じた結節の性状学锶察した。

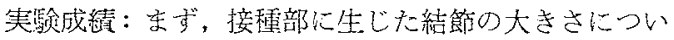
て述ベる。

結節の大ささ学眼報の判定規準 ${ }^{11}$ に従つて浿定し，そ の平均指数より結節の堌大度定示したものが図1である

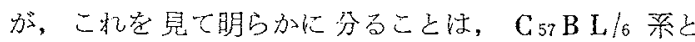
$\mathrm{C}_{3} \mathrm{H}$ 系が全く正反対のしか子著しい特徽定示している ことである。

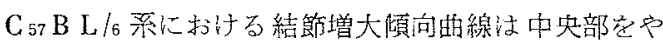

Fig. 1. The Susceptibility to Murine Leprosy Bacilli of Various Inbred Strains of Mice

Mice were inoculated subcutaneously with $0.25 \mathrm{cc}$ of a $10^{-2}$ suspension prepared from subcutaneous leproma.

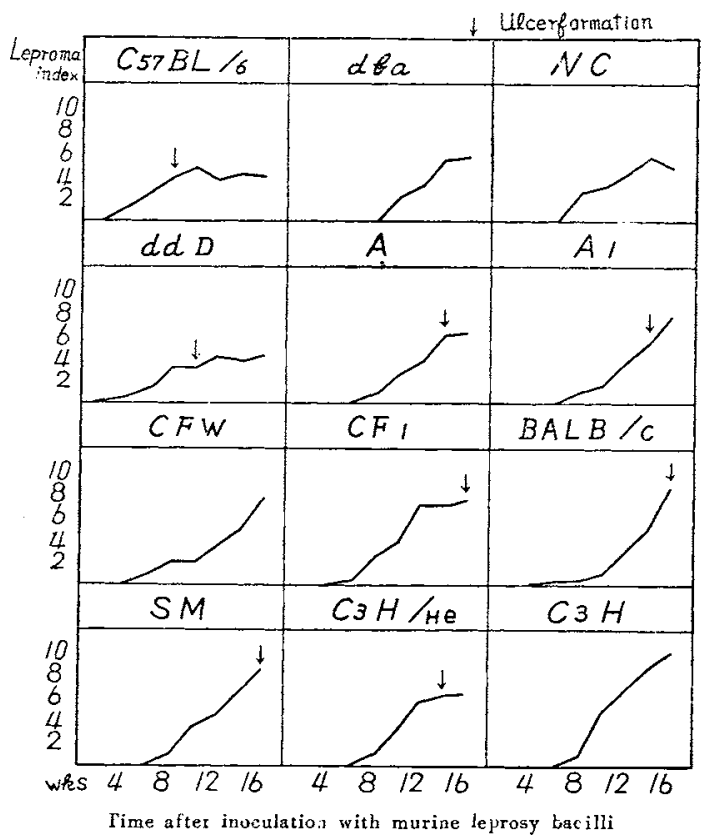


や左端より横に走り， С $3 \mathrm{H}$ 系のそれはやや右にかたを

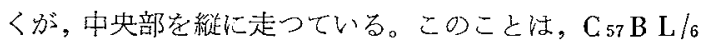
莱仙いては，結節安早く触机ることは出来るが，それ はあまり大きくならず，そのままほほぼその大きさを持

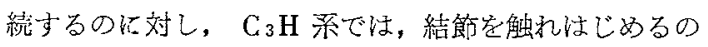
は遅いが，明瞭に触狆てから後は急速にその大きさを堌 し，遂には大結節となることを良くあらわしている。 また他の系統はすべて上記系統の中間の性質を示し， それで机が，或は $\mathrm{C}_{57} \mathrm{~B} \mathrm{~L} / 6$ 梁に，或は $\mathrm{C}_{3} \mathrm{H}$ 系に近い 性質をもつことも図1觉見れば明らかである。

このような, 系統による著しい経過の相違は, それぞ れの結節性状に大きな美異があることによるように思わ れる。

そとで，著しい特徖を示した前記 2 系統の結節性状に ついて検討してみよう。

$\mathrm{C}_{57} \mathrm{~B} \mathrm{~L} / 6$ 系の結節注終始硬い限局性のものであつて，

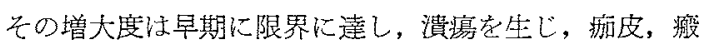
壆の時期を経過して必らず結節の縮小をみるので西る。

一方， $\mathrm{C}_{3} \mathrm{H}$ 系の結節は，初期はただ厚みとして触れ， 次第に㵀漫性の軟い結節となり，その大きさ名拇指頭大 を越えるようになるが，結節の性状にはあまり变化がな く，末期には潰嫁を歹ることもあるが，全経過を通じて 病勢減退の傾向が全くみられない。

次に，他の采統の結節性状についていえば，結節の性 状は図 1 にみる結節増大傾向曲線とよく平行し，これが $\mathrm{C}_{57}$ B L/6 系に近いものは結節性状もまた $\mathrm{C}_{57} \mathrm{~B} \mathrm{~L} / 6$ 系 に近く， C $3 \mathrm{H}$ 柔に似ている場合は，その結節性状も亦 た $\mathrm{C}_{3} \mathrm{H}$ 柔にかなりよく促ていることが分つた。

それ故に，C 57 B L/6 系に俣て，硬い，限局性の小結節 示すことは, その経過も考虑に入れると, 宿主のすつ 鼠瀨菌炕対寸る抵抗性の現われのように思われる。をこ でこのよらな性質を示すものを良性の結節と乎びたい。

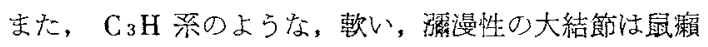
菌に対する抵抗性が極好て少い場合にあらわれるものと

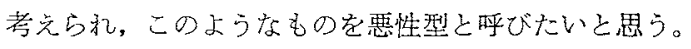

以上のように，鼠癭の皮下結節を，その性状により， 良性型々悪性型に分けて, 改的て他の10系統のマウスに 生ずる結節の型を分類すると， $\mathrm{C}_{57} \mathrm{~B} \mathrm{~L} / 6$ 系のように良 性型の結節を明らかに示するのは ddD，N C 系などであ り、ここに載せなかつたが $\mathrm{dd} \mathrm{Y}$ 系もまたこの型の結節

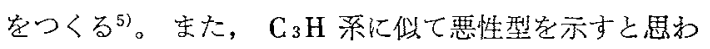
れるるのは BALB $/ \mathrm{c}, A_{1}$ 系などであつて，他の系統はほ ば中間の性質を示すが，どちらかといえば良性型に近い よらに思わ礼た。

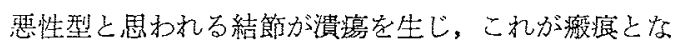

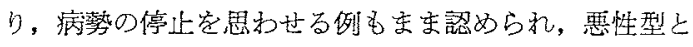
しての性質を最後まで示与系統はかなり少いように思わ れた。

\section{鼠㿎の経過と病型との関係}

鼠瀨を良性型と悪性型と认分けることを前の項で提唱 したが，このような型の鼠瀬がごのような経過および予 後宗示かを，それぞれの代表的采統について観察した ので，その成績について述べる。

\section{実験：鼠攋の経過}

実験材料抢よび方法：良性型，および，恶性型を示す 系統として，それ卆れ $\mathrm{C}_{57} \mathrm{~B} \mathrm{~L} / 6$ 系と ddY 系間の雑種 第 1 代 $\left[\left(\mathrm{C}_{57} \mathrm{~B} \mathrm{~L} / 6 \times \mathrm{ddY}\right) \mathrm{F}_{1}\right] ， \mathrm{C}_{3} \mathrm{H}$ 梁と ddD 系閣 の雑䅣第 6 代 $\left[\left(\mathrm{C}_{3} \mathrm{H} \times \mathrm{ddD}\right) \mathrm{F}_{6}\right]$ を選び，これらの生 後約4週のものを実跧に使用した。

上記マウスの前胸部に，鼠㴭菌ハワイ株の100 倍乳済 $0.25 \mathrm{cc}$ を皮下接種し，接種後 2 週枋きに，40週むで接 程部に生ずる結節をとの性状它中心として䔘察した。

なお，結節の大きさの判定は既報の規準りに従い，ま た，性状の変化については表に示したように，脱毛，潰 癔, 痂皮，疫痕の状龍をそれぞれ結節の大きさとともに 記載しておいた。

実験成績：まず，琹性型の例について述べる。

表1に明らかなように，使用したマウスの性質は $\mathrm{C}_{3}$ H梨に極为て近いもので市つた。

8 週穼では結節を触れないが，10週目より厚みとして 触れ出し，以後急速に大きさ学增卞。16週目には拇指頭 大程度に達し，18週目頃より結節部に脱毛がみられ，潰

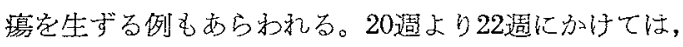
結節は大きな和皮に被れ，その大きさむ多少減ずるよう である。この特期定過ぎると, マゥスの体調に悪化が諗 められ，体重は減少し，毛づゃも衰えてくる。26週頃か ら死亡主る例が热められるようになり，32遗㥧索でに全 例が死亡した。

一方, 対照として, 生理食塩水のみを注射し，そのま ま同樣に飼育してきた同柔統のマウスには，40週を経過 しても，全く異常が認好られなからた。

以上の点から，との系統では，鼠瀬は恢復することな く，健康マウスより死の転帰をとることが早いことが分 つた。悪性型と呼ぶこと梳当を得ているものと思う。

次に，良性型の例について述べる。

表2をみれば明らかなように,この場合む使用したマ ウスの性筫は $\mathrm{C}_{57} \mathrm{~B} \mathrm{~L} / 6$ 系に近いものであつた。 
Table 1. The Course of Malignant Mouse Leprosy

Black mice of $\left(\mathrm{C}_{3} \mathrm{H} \times \mathrm{ddD}\right) \mathrm{F}_{6}, 4$ weeks of age, were used.

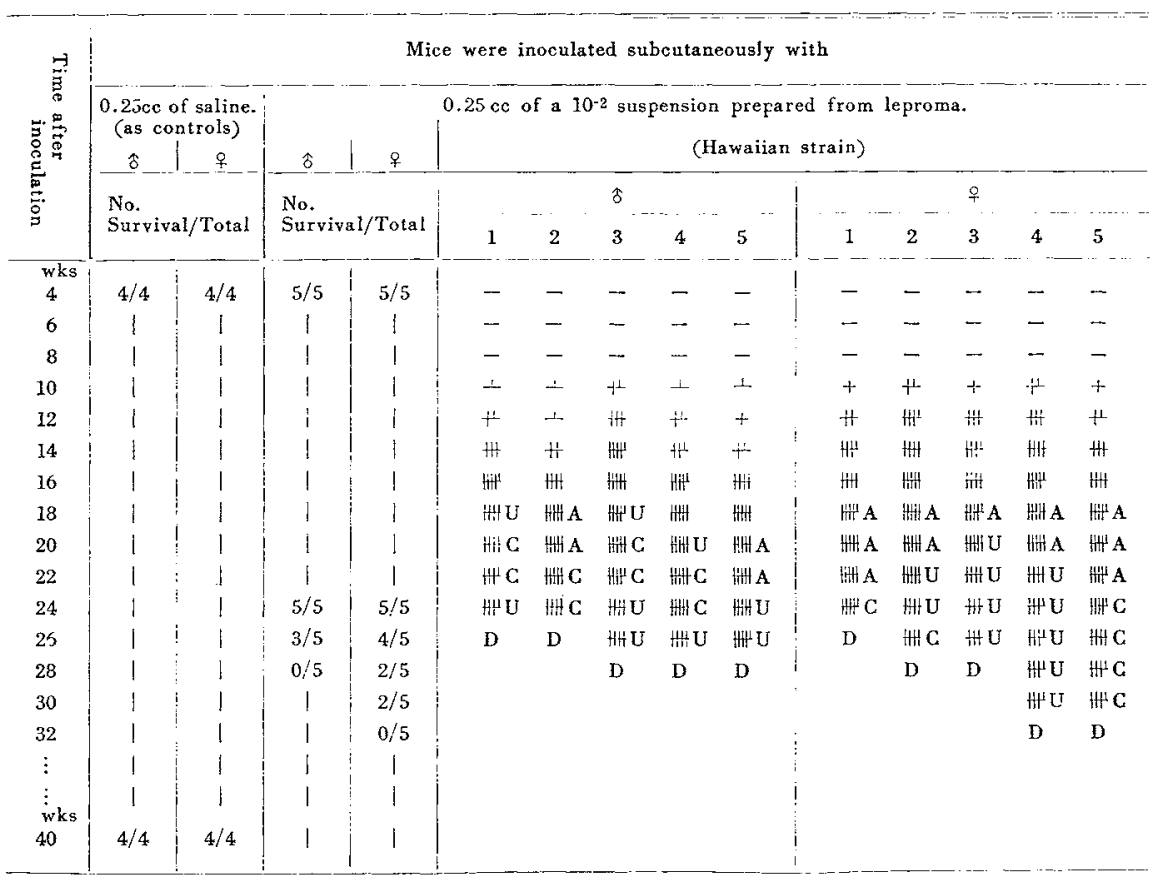

A : Alopecia, U: Ulcer, C: Crust, D: Death.

Table 2. The Course of Benign Mouse Leprosy

Black mice of $\left(C_{\mathrm{Fq}} \mathrm{BL} / 6 \times \mathrm{ddY}\right) \mathrm{F}_{1}, 4$ weeks of age, were used.

\begin{tabular}{|c|c|c|c|c|c|c|c|c|c|c|c|c|}
\hline \multirow{5}{*}{ 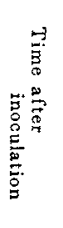 } & \multicolumn{12}{|c|}{ Mice were inoculated subcutaneously with } \\
\hline & \multicolumn{4}{|c|}{$\begin{array}{l}0.25 c c \text { of saline } \\
\text { (as controls) }\end{array}$} & \multirow{2}{*}{\multicolumn{6}{|c|}{$\begin{array}{c}0.25 \text { ec of a } 10^{-2} \text { suspension prepared from leproma. } \\
\text { (Hawaiian strain) }\end{array}$}} & & \\
\hline & $\hat{\xi}$ & q & $\hat{o}$ & 우 & & & & & & & & \\
\hline & \multirow{2}{*}{\multicolumn{2}{|c|}{$\begin{array}{l}\text { No. } \\
\text { Survival/Total }\end{array}$}} & \multirow{2}{*}{\multicolumn{2}{|c|}{$\begin{array}{l}\text { No. } \\
\text { Survival/Tota } 1\end{array}$}} & \multicolumn{4}{|c|}{ 今 } & \multicolumn{3}{|c|}{$q$} & \\
\hline & & & & & 1 & 2 & 3 & 4 & 1 & 2 & 3 & 4 \\
\hline wks & & & & & & & & & & & . & \\
\hline 4 & $4 / 4$ & $4 / 4$ & $4 / 4$ & $4 / 4$ & $\perp$ & $\perp$ & - & - & + & $\perp$ & 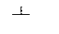 & - \\
\hline 6 & 1 & 1 & 1 & 1 & H & $H$ & \pm & + & $H$ & $t$ & + & + \\
\hline 8 & 1 & 1 & 1 & 1 & 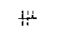 & $\mathbb{H}^{\prime}$ & $H$ & $\div$ & $H$ & \# & + & + \\
\hline 10 & 1 & 1 & 1 & 1 & HA & $H A$ & $\mathbb{H}^{\mathrm{A}} \mathbf{A}$ & $H^{i}$ & HA & $H$ & + & $H$ \\
\hline 12 & 1 & 1 & i & I & mU & $H A$ & $H A$ & \# & HA & $\ddot{11}$ & HA & t \\
\hline 14 & 1 & 1 & 1 & 1 & $+1 \mathrm{C}$ & HA & \#A & $H^{\prime} \mathrm{U}$ & HA & HU & $+A$ & $H$ \\
\hline 16 & 1 & 1 & 1 & 1 & $\because \mathrm{C}$ & 斗 & $H^{1} \mathbf{A}$ & $\mathbb{H}^{1} \mathrm{U}$ & $+\mathbf{A}$ & $+\mathrm{C}$ & $+\mathbf{A}$ & $+\mathrm{A}$ \\
\hline 18 & 1 & 1 & 1 & 1 & $+\mathrm{C}$ & $H A$ & HA & $\# U$ & $\mathrm{HC}$ & $\perp_{\mathrm{A}}$ & $+\mathrm{C}$ & $\# \mathbf{A}$ \\
\hline 20 & 1 & 1 & 1 & 1 & $+\mathrm{C}$ & $+s$ & 妍A & HS & $+S$ & $-? A$ & $+S$ & $+\mathrm{A}$ \\
\hline 22 & 1 & 1 & 1 & 1 & $+\mathbf{C}$ & $-? \mathrm{~A}$ & $H^{H} \mathbf{A}$ & Hs & $+s$ & $\rightarrow ? A$ & $\perp_{\mathbf{A}}$ & $+\mathrm{A}$ \\
\hline 24 & 1 & 1 & 1 & I & $+s$ & $-?_{A}^{A}$ & $+s$ & $-? \mathrm{~A}$ & $+s$ & $-? \mathrm{~A}$ & $\therefore \mathrm{A}$ & $+\mathrm{A}$ \\
\hline 26 & 1 & 1 & 1 & 1 & $+\mathrm{s}$ & $-? A$ & $H S$ & $-? A$ & $+\mathrm{s}$ & $-? \mathrm{~A}$ & $\perp_{\mathbf{A}}$ & $\perp A$ \\
\hline 28 & 1 & 1 & 1 & 1 & $+\mathbf{s}$ & $-?$ & HS & $-? \mathrm{~A}$ & $+\mathrm{A}$ & -? & $-A$ & $+\mathrm{A}$ \\
\hline 30 & 1 & 1 & 1 & 1 & $+s$ & - & $\mathrm{HU}$ & $i s$ & $+s$ & $-?$ & $\perp_{A}$ & $+\mathrm{A}$ \\
\hline 32 & 1 & 1 & 1 & 1 & $+s$ & - & HS & $-? \mathrm{~A}$ & $+\mathbf{A}$ & $-?$ & $\perp_{\mathbf{A}}$ & $+\mathrm{A}$ \\
\hline$\vdots$ & 1 & i & I & 1 & 1 & 1 & 1 & 1 & 1 & 1 & 1 & 1 \\
\hline$\vdots$ & 1 & 1 & 1 & 1 & 1 & 1 & 1 & 1 & 1 & 1 & 1 & 1 \\
\hline 40 & $4 / 4$ & $4 / 4$ & $4 / 4$ & $4 / 4$ & $+\mathrm{S}$ & - & \#s & $-? A$ & $+\boldsymbol{A}$ & $-?$ & $\stackrel{\perp}{A}$ & $+\mathbf{A}$ \\
\hline
\end{tabular}

A : Alopecia, U: Ulcer, C: Crust, S: Scar. 
接種徭 2 ないし4週目にすでに結節を触れる例があり 6 週目には全例に小結節を触れる。以後，結節の大きさ は慬かに増すが，10，12週頃でその大きさも限界に達 し，たかだか小指頭大前後のものに過ざない。丁度，こ の頃より結節部に脱毛が办られるようになり，12週目ふ らは潰瘄も認められるようになる。この漬痛は或る例で は直ちに小痂皮で被机，痂皮がとれて般寔となるが，或 る例では比較的㫳く潰提が残つている。大体，20週頃よ り大部分の結節に縮小が虫められるようになり，てれで 机程度こそ違光，極めて小さな結節老残して以後は殆え ど病勢の変化炎めらわさない。

また観察期間中，対照として飼盲しておいた同系統の 健康マウスと，この良性型の雁患マウスの間に，健庭状 態で证何等異る点が見出せなかつた。

以上の点から，この系統では，病気は必らず恢復に向 い，長い経過をとる。そして，型患マウスは時に治癒

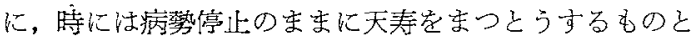
思われる。主性型と呼ぶにふさわしい経過とい方るであ ろう。

\section{鼠痳菌に対する抵抗性と発現する 病型टの関䋆}

鼠獺の経過加その病型により著しく異ることは，窗主 の侵入菌に対する抵抗の現わ玌であつて，このことは両 病型における結節発生状態の善学見れば明らが分るも のである。

実験 I：接種菌量等しくし，菌液量变变え た場合の結節発生状態

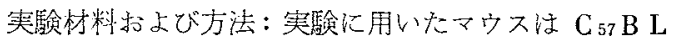
16系，市よび C $3 \mathrm{H}$ 系のそ机卆生後4違のものであつ て, 各系統10匹ずつである。

そ虬无れの半数にハワイ株 100 倍乳偊の $0.1 \mathrm{cc}$ ずつ 艺，䂝りの半数には400倍乳珴の $0.4 \mathrm{cc}$ ずつを，前胸 部の皮下に接種した。

これらマウスにつけて，接種後 4違目より，2週敌き に16週まで，再系間の結節発生状態を観察した。钼察方 法は前項の方法と同様である。

実稌成縝：成續は一括して表 3 に示した。

Table 3. Development of Leproma in Benign and Malignant

Types of Mouse Leprosy

\begin{tabular}{|c|c|c|c|c|c|c|c|c|c|c|c|c|c|c|c|c|c|c|c|c|c|}
\hline & & \multicolumn{10}{|c|}{$\mathrm{C}_{57} \mathrm{BL} / \mathrm{6}$ (Benign Type) } & \multicolumn{10}{|c|}{$\mathrm{C}_{3} \mathrm{H}$ (Malignant Type) } \\
\hline & & \multicolumn{10}{|c|}{ Mice were inoculated subcutaneously with } & \multicolumn{10}{|c|}{ Mice were inoculated subcutaneously with } \\
\hline & & \multicolumn{5}{|c|}{$0.1 \mathrm{cc}$ of a $1: 100$ suspension. } & \multicolumn{5}{|c|}{$0.4 \mathrm{cc}$ of a $1: 400$ suspension. } & \multicolumn{5}{|c|}{$0.1 \mathrm{ec}$ of a $1: 100$ suspension. } & \multicolumn{5}{|c|}{$0.4 \mathrm{cc}$ of a $1: 400$ suspension. } \\
\hline Mouse & No. & 1 & 2 & 3 & 4 & 5 & 1 & 2 & 3 & 4 & 5 & 1 & 2 & 3 & 4 & 5 & 1 & 2 & 3 & 4 & 5 \\
\hline \multirow{7}{*}{ 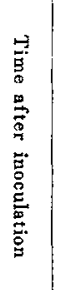 } & 4 & + & $\perp$ & 1 & - & - & - & - & - & - & - & - & - & - & - & - & - & - & - & - & - \\
\hline & 6 & + & $H$ & $\ddot{H}$ & + & + & 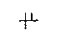 & + & $\perp$ & - & - & - & - & - & - & - & - & - & - & - & - \\
\hline & 10 & $\oplus$ & + & $\oplus$ & + & + & $H$ & + & H & + & + & - & - & - & - & - & - & - & - & - & - \\
\hline & 12 & (1) & + & (1) & H & $H$ & $\frac{111}{41}$ & $H$ & $\frac{11}{11}$ & $H$ & + & + & $\perp$ & $\perp$ & $\perp$ & $\perp$ & $\perp$ & $\perp$ & $\perp$ & $\perp$ & - \\
\hline & 14 & $\oplus$ & $\oplus$ & (9) & (4) & (1) & $\mathrm{HH}^{\mathrm{H}}$ & $t^{\prime}$ & $\ddot{H}$ & $t_{1}^{1 \pm}$ & +1 & $\ddot{H}$ & it & \# & tt & H & $H$ & $H$ & + & + & + \\
\hline & 16 & $\oplus$ & (1) & $\oplus$ & (1) & $\oplus$ & $H^{H}$ & (サ) & +4 & $\#$ & $H$ & H & 州 & $H \mu$ & $\mathbb{H}^{\prime}$ & 话 & HH & $H$ & $H H$ & $H^{\prime \prime}$ & Hit \\
\hline & 16 & \pm & $\oplus$ & $\oplus$ & $(9$ & $\oplus$ & $H^{2}$ & (1) & $\frac{11:}{1 !}$ & $\frac{11}{I^{2}}$ & $H$ & (1ii) & 排 & HH & $H_{11}$ & $f i^{\prime \prime}$ & $\mathrm{HWH}$ & initi & HiH & filt & 泚 \\
\hline \multicolumn{2}{|c|}{$\begin{array}{l}\text { Weight of } \\
\text { leproma, mg }\end{array}$} & 20 & 50 & $\mathrm{O}_{20}$ & $\mathrm{O}_{50}$ & 10 & 24.0 & 100 & 230 & 200 & 60 & $O_{650}$ & 720 & 700 & 590 & 540 & 1040 & 1300 & 1050 & 1030 & 1000 \\
\hline
\end{tabular}

: Ulcer

まず， $\mathrm{C}_{57} \mathrm{~B} \mathrm{~L} / 6$ 系に括いては，0.1 ce 注射群に結節 を早く触れる例が多い。しかし，この結節はあ屯り大き

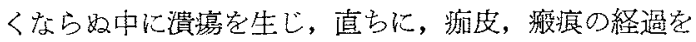
とり，著明な縮小を示す。一力，0.4 cc 注射群の結節は 僅かに発生が幄れるが，大きさはやや大きく，観察期間 中にはその縮小が热められなわつた。
次に, $\mathrm{C}_{3} \mathrm{H}$ 采においては, $0.1 \mathrm{cc}$ 注射群子 $0.4 \mathrm{cc}$ 注 射群も特に大差がなく, ともに結節注著しく增大し, 後 者の結節がやや大きい程度であつた。

以上のことから次のように考えたい。たとえ接㻎され た菌量が同じでも，液量が異なれば，宿主内での侵入菌 の着林範囲が異なつてくる。 $\mathrm{C}_{57} \mathrm{~B} \mathrm{L/6}$ 系すなから， 


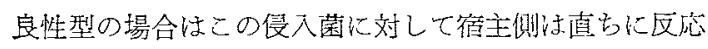

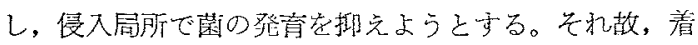
床䉓囲のせ要い $0.1 \mathrm{cc}$ 注射群に和いては極めて小さな結 節をつくるに過ぎず，その螌围が広くなれば，それに応 した大きさの結節它つくるものと思秃る。

これに反して， $\mathrm{C}_{3} \mathrm{H}$ 系，李なbち，恥性型の場合は 侵入菌に対する宿主側の抵抗が極奶て弱いものと思わ肌 る。そこで，最初は明瞭な結節友触れないが，濑次大き

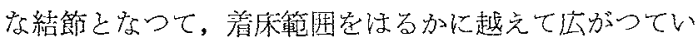
く。侵入菌の着床範囲に差があれば，初期法去の結節の 大きさにも差が諗めら礼るが，後に怔然同程度の大き さとなるであるう。

このように，良性型では，接種された菌奔直ちにその

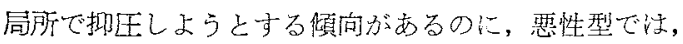
このような傾向注全く認められない。

このことは次に述べる実䮖成績より更に一㞗明瞭しな ろう。

実験 2: 同一菌液の少量索近接した二力所に皮下 接種した場合の結節発生状態

実駼材料吉よび方法：使用したマウス汪（C.57 B L/6X

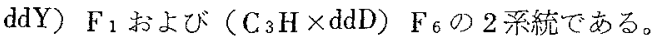

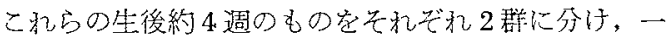
方以は，ハワイ株の100倍乳成肎 $0.1 \mathrm{cc}$ ずつ，前胸部 皮下の近接した 2 力所に接種し，他方には，同じ乳阂の $0.2 \mathrm{cc}$ 学同様に 1 力所に接種した。

接種部に生じた結節の状態を前実霝と同じ規準で，接 種後18週まで, 観察し, 両系統間の美異について検討し to.

実験成績：良性型の（C 57 B L/6 $\times$ ddY） F 1 の場合， 2 力所に接種されたマウスにおいては，1力所に接種さ れた例に生ずるものの約半分注どの結節が 2 ב別々に生 ずる。これらは経過とともに時に憶合することもある が，大部分は常に2 2 の結節として終始する。

ところ炽，悪性型 $\left(\mathrm{C}_{3} \mathrm{H} \times \mathrm{ddD}\right) \mathbf{F}_{6}$ の場合注雨群間 の差は良性型の場合汪ど著明ではない。初期はともに厚 みとして結節を触わ，以後，急速に增大方る。2力所に 接稦した例で洼，時にくびれのある結節として触れるこ ともあるが，結節は常に密に济合して秥り，その大きさ， 経過も他の例とほぼ同程宽であつた。

このことふら，良性型においては，接種された菌液は 全体がーつの算位となつて，そこに結節が生じ，窞主側 は病変の発屒要その局所で抑仺しようとするのに対し， 瑟性型においては，接種された菌は殆えど宿主側の抵抗 定らけず, 個々の菌, 或は菌群をえれぞれ一つの単位と

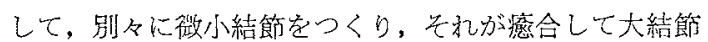
となり，さらに外部に垃大していくよらに思わ的る。

\section{免疫または治療による病型の変化}

鼠演に対する䍜患素質は先天的なものであり，その発 現する病型はマウスが生れながらにしてもつ青因による ものであると考えているが，この病型の発現は果して一 定不变のものであろらか，またはなんらかの刺战が誘因 となつて，他の型变る場合も起り得るであ万うか，こ

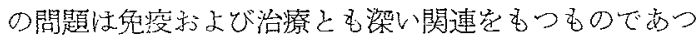
て，是非研究して执か秝ばならないものと思ら。

今までの観察の結果方，良性型より悪性型に变つた 例定明確に指摘主ることは出来ないが, 刑性型であるべ きすのが，良性型としてあらわれた例の二，三について ここ赫皆する。

実験 1：鼠㿎の発症進鼠に対する B C G の效果

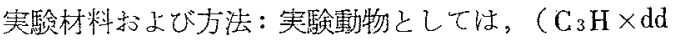

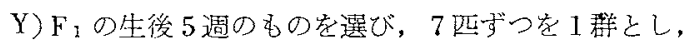
B C G $2 \mathrm{mg}$ 腹腔内纯究群定 2 群と，対照として生理食 㦈水の多它注的した群客 2 群つくつた。

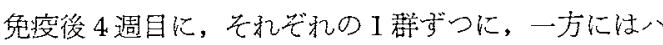
ワイ株 100 倍乳風の 0.25 ce ずつを，他方には同じく 10000 倍乳風の $0.25 \mathrm{cc}$ ずつを前胸部皮下に接種した。

観察期間は攻擊後 6 週目より18造までであり，観察方 法は前可妾での実験と同様でここではとくに接種部に 生じた結節の病型等中心にした。

共験成績：成績は表 4 K示す通りであつて，単に，結 節の大きさの文比較しても，充分B C G の饺果がある ことは分るであるら。しかし，病型についてみ和ば，そ の效果は更に一層明賭となるのである。

100 倍乳偊接種例において，B C G 群の結節は最初よ りすべて良性型の像莸あらわすが, 対照群中の過半数は

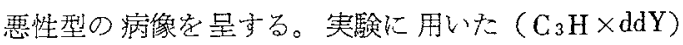
$\mathrm{F}_{1}$ は, 近交系である $\mathrm{C}_{3} \mathrm{H}$ 䒺のように, 全例が悪性型 姿示すものではないが，大の大部分が瑟性型となること は対照例の成樍文れれ゙明らかであるう。とれ故にB C G群中に瑟性型のあらわ秃なかつたととは，当然，覀性 型となるべきものが，良性型を呈したと考えうるわけで あつてここに B C G 免度の特徽があるように思われ 子。

接種後 $10 ， 12$ 週目の所見では，BCG群の結節が，大 きさで，対照群に勝つているが，病型荧考慮に入行る らば，以後の経過は自ら明蹽であつて，判定に支障を来 たすことはあるまい。病型を中心とした判定が他に勝る 
Table 4. Development of Leproma in Mice Challenged 4. Weeks after BCG Vaccination Agouti mice of $\left(\mathrm{C}_{3} \mathrm{H} \times \mathrm{dd} \mathrm{Y}\right) \mathrm{F}_{1}, 5$ weeks of age, were used.

\begin{tabular}{l|l} 
Mice were injected intraperitoneally with \\
$2.0 \mathrm{mg}$ Of BCG. & $0.2 \mathrm{cc}$ of physiol. saline, as controls. \\
\hline
\end{tabular}

Mice were challenged subcutaneously with $0.25 \mathrm{cc}$ of a $10^{-2}$ suspension 4 weeks after vaccination.

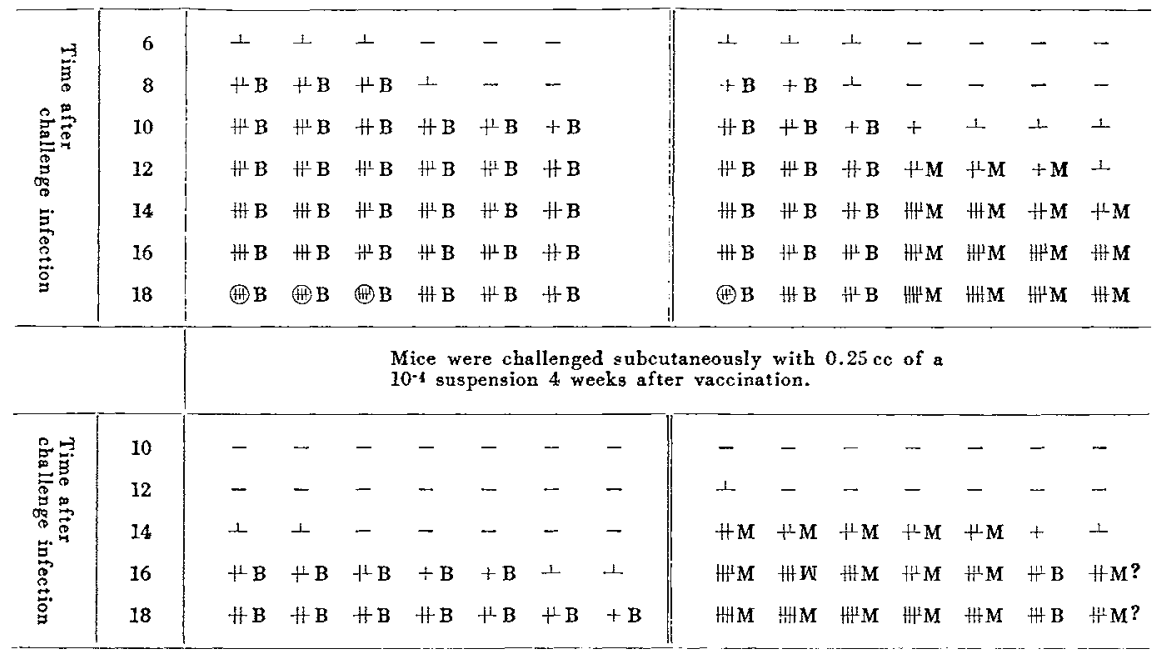

$B$ : The feature of benign type

$0:$ Ulcer

$M$ : The feature of malignant type

点はここにあるのである。

次に，10000倍乳剂接種例についてで亦るが，この場 合は，対照群が 1 例を除きみな悪性型の大結節となり， B C G 群が良性型の小結節沉とどをつた沈め,さらに判 定が容易で，明解であつた。

実験 2：INAHKよる鼠㾋の治療実験

実験材料䄱よび方法：実験に用いたマウスは $\mathrm{C}_{3} \mathrm{H}$ 采

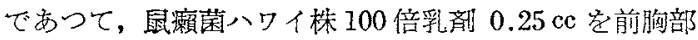
皮下に接種し，12週後，小指頭大の悪性型結節を触れる 時期から薬凧の投与を開始した。

使用した薬刋はイソニコチン酸ヒドラジット（I N A H），およびストレプトマイシン（SM）で亦つて，前 者は1日 $1.0 \mathrm{mg}$ ，後者は $2.0 \mathrm{mg}$ を，週6日法により， 10 週間継続して腹腔内に投与した。なお，対照として は，生理食塩水のみの $0.2 \mathrm{cc}$ 同様に注射したるのを おいた。

観察方法注前回安でと全く同様である。

実験成績：接種後 12 週目の，明瞭な結節定触れるマウ スに IN A H を投与すると，結節はまずその硬さを增し 境界が明嘹化分るようになる。主なわち，覀性型の像か ら良性型の像に変つてくるのである。以後，さらにこれ
による治療をつづけると， $\mathrm{C}_{3} \mathrm{H}$ 系においても，結節は 良性型の経過をとるょうになり，遂には結節を殆えど触 れなくなる例をある。

ところが，SMによる治潦で注，結節の状態に全く変 化がみられず，結節は，如何飞治燎をつら゙けてる，対照 例之同㥞の悪性型の像定示し続ける。

SMがINAH z異り, 鼠穎に対する沿療効果安示さ ないこと性，病型が刑性型の实まで良性型に変らないこ そから文ても明らかであるう。悪性型から良性型㴼像 が変ることは治療効果があがつている証揵の一つである といらことが出来る。

考察

マウスに鼠顁菌を皮下接種し，接種部位に生ずる結節 の性状から，鼠攋良性型と悪性型に大別出来ることは すでに述べた通りであるが，この雨病型における病気の 経過定詳細に観察したところ，これらはさらにいくつか の病期に分けることが出来るように思われる。

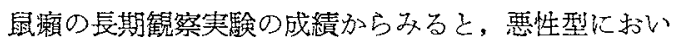
ては, 感染後比較的長い潜伏期艻㐫り，つぎに進行期に 入り，漬愓期を経て，終末期に達し，死に至るもので， 
経過としては短く, 予後の悪いものといえよう。次に, 恶性型の場合と同㥞に，良性型の経過を病期に分けると 感染後短い潜伏期の後に，進行期より漬瑝期に向うが， この型で㤬，以後，退行期から停止期を経過する点が恶 性型と㖕つている。停止期は長く，そのまま経過する例

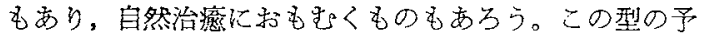
後は良いものということが出来る。

以上の上らな両病型の経過案図示すれば図 2 のうに なる。

しかし、このような経過は雨型ともに典型的な列のる

Fig. 2. The Course of Mouse Leprosy (I)

(In the cases inoculated with I: 100 suspension)

Benign Type (in $\mathrm{C}_{57} \mathrm{BL} / 6$ )

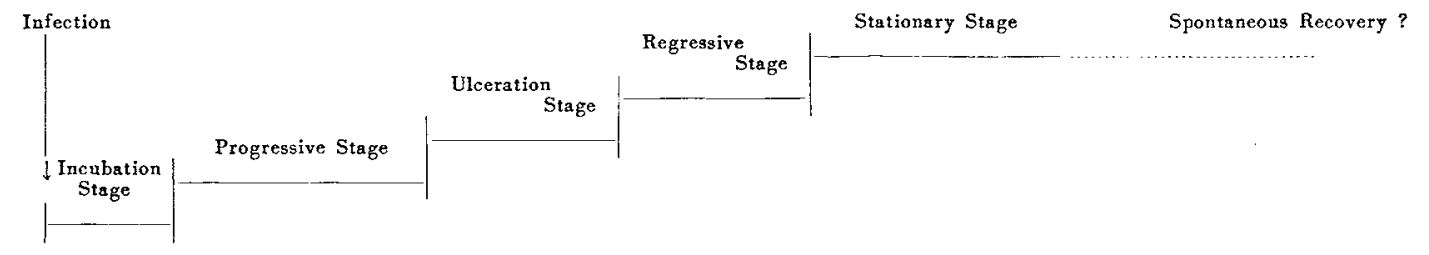

Malignant Type (in $\mathrm{C}_{3} \mathrm{H}$ )

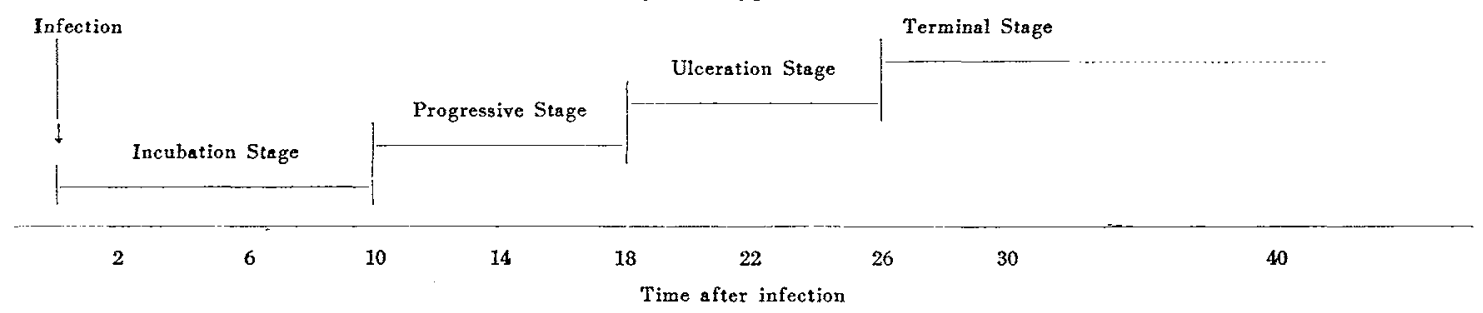

のであつて，これと異る経過をとつた例も，別の機会に 少数ながら経験している。

まず，悪性型の場合については，漬脜が痞皮で被れ， さらに㓔痕となつて後に病勢が停卡する例がときに晃 られる。この際の結節は極めて限局性の硬いむのに変つ ている。それ故，覀性型の経䢔中にす停止期があると考 えるよりは，菌力と宿主の抵抗力との関䋆に変化がおき， 悪性型から良性型への移行が起つたと考える方が，この 場合は，適当と思われる。
次に，良性型の場合であるぶ，停止期中に接種部位を 中心として大濽瘍を作り，マウスは衰哥して遂には死亡

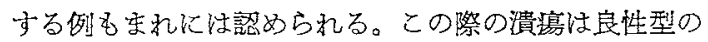
それと異り，かなり大きいばかりでなく，病変の周辺部 は健唐部との境界が明瞭でない。そこでこの揚合も，良 性型に再潰癔期，終末期を考えるよりは，瑟性型の漬㿋 期に移行したものと考壳たい。

以上のような考えから, 雨病型間の病変の転換, 移行 の状態学想定し，図示主ると四3のようになる。

Fig. 3. The Course of Mouse Leprosy (II)

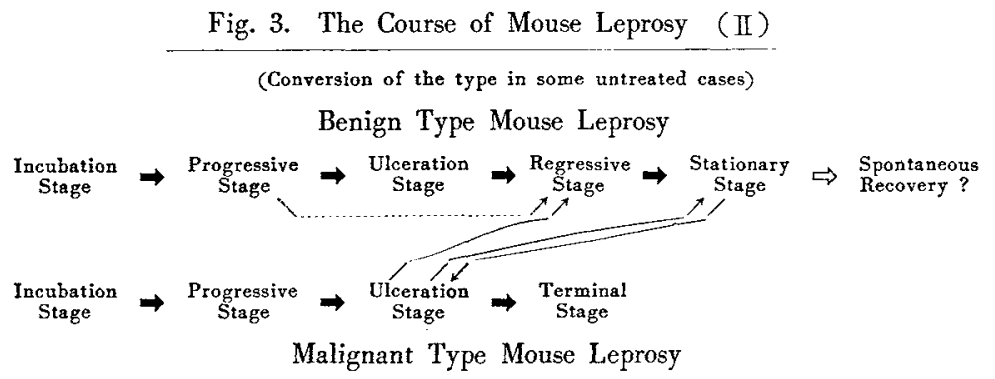

鼠癩の分類には，前にも述べたように，多くの方式が 発表されているが，いずれも，自然鼠蕀検索の際に，鼠 瀨菌のみによつて起る所㯰真性鼠瀨と，他の抗酸菌によ
万仮性鼠攋，また性雨者の淈合等を分類するためのもの であつて，真性鼠癩を分類す尚昜合には，Stefansky の 病型をてのまま踏襲しているに過ぎない。 
そこで，今までに述べてきた雨病型の病期老対照とし て，病期を表現するものとい秃る Stefansky の病型を みてみよう。

まず，淋巴腺型には，両病型の進行期の初期があたる ことは当然として，同時に良性型の停止期も合まれる場

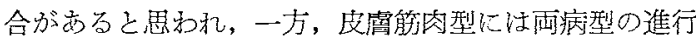
期，潰富期があたるとともに，良性型の退行期もこれに 入ることに京るう。

そ秃故，Stefansky の分類は病型上は関係なく，病势 をあらわすともい光ず，さらに病期というには福雑にす ぎるものと考充る。

さて，以上述べてきたように，鼠癩菌定皮下接種した 場合に，マウスの采統により，著しく異つた性留をむつ 結節のあらわれることが明らかとなつたが，この著明な 差方㜚主のもつ鼠攋菌に対する抵抗性にもとずくもので あることも第 4 項の実験成績よりまを朋膫であ万う。

マウスに鼠瀨菌劣皮下接檑した場合，宿主侧のこれに 対する抵抗性が強ければ，病型は良性型に，弱け狆ば瑟 性型に㛎らかれるものと考えているが，ここで，さらに 両病型に扮ける結節の病理組織所見について旊単にふれ 参考に供したい。

鼠瀨の病型分類に関する病理組織学的研究の詳細惊別 の機会にゆずり，ここでは，一応代表的な例，ななわち $\mathrm{C}_{57} \mathrm{~B} \mathrm{~L} / 6$ 禾，および $\mathrm{C}_{3} \mathrm{H}$ 梁の結節組織像についての み簡単炕報告するにとどわる。

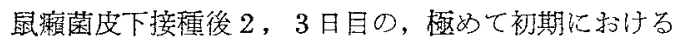

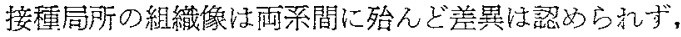

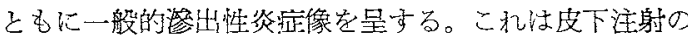
機械的刺线にむよることであろうが，接種菌夜中に含ま れる死菌および組織成分の影響が大きいものと考完られ る。

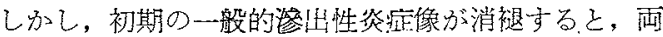
系間の差注著明なものとなり，この善は感染後期に至つ ても能然として変るところがない。

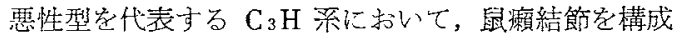
する細胞群炡菌の充満した円型鼠潡細胞のみといつてよ く, 類上皮細胞の出現, 結合線維の增殖, 单球, リンパ 球，および形質細胞等の炎症性絧胞浸潤は殆えど認めら 机ない。

一方，息性型の $\mathrm{C}_{57} / \mathrm{B} \mathrm{L}_{6}$ 采に括いても，結節中に鼠 瀨細胞の多いことは当然であるが，これらの鼠攋細胞は 円型上り，星型，不定型への移行が多く，類上皮細胞の 新生むか店り認められ，結節周囲に線維芽細胞，打よび 結合線維の增成が著しく、これらは次第に結節内部に侵
入し，このた孜結節は分某状を旺するよらになる。また 結節周迅部，和よび盈管周团性に著明なりンハ球浸潤が 䖵められる。

このような所見からみても，悪性型の場合は，鼠淘菌 に対主る宿主侧組織の生体反広が稌めて少く，乙机に反 して，良性型の場合には鼠顆菌に対する強い生体防衛反 応方認內られ，先天的抵抗性が明らかに現わ机ているす のと考皇る。

なお，これら組織所見の，覀性型の場合は，緒方，福

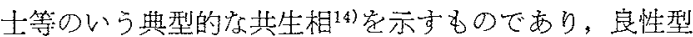
の場合は，結節周辺より類上皮細胞性肉犽腫の形成が認 氻られるところ㔔ら，其生相より肉茅相14)への移行像を 示すむのと思す机る。

今まで遮べてきたように，発現する病型と宿主の抵 抗性の閻に密接な関係のあることは明らかであるが、こ の鼠㴭菌に対する抵抗性が先天的素因にもとずくもので あることは，近交系マウス間の交配により得ら礼た杂系 マウスにおける笑駗成績4)和らて明らかである。

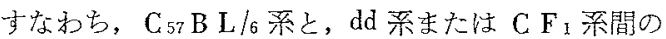
雑種はすべて $\mathrm{C}_{57} \mathrm{~B} \mathrm{~L} / 6$ 采に， $\mathrm{C}_{3} \mathrm{H}$ 系之， dd 系または $\mathrm{C} \mathrm{F}_{1}$ 系間の雑種はすべて $\mathrm{C}_{3} \mathrm{H}$ 系に良く僬た感受性を 示し，しかも， $\mathrm{C}_{57} \mathrm{~B} \mathrm{~L} / 6$ 系と $\mathrm{C}_{3} \mathrm{H}$ 系間の雑種恔親、 ウスの特徵を失い，両系の中間の性質を示した。このこ とは感受性系之抵抗性系の交配に際してみられ方羅虫因 子の遗伝について行われた Webster ${ }^{15)}$ ，および Gowen \& Schott ${ }^{16)}$ の成績と極为てよく倾ていた。

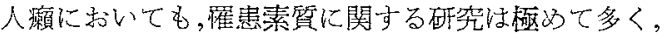
瀨の家族関係についての系統的研究加ら，これの存在を 肯定するものも少くない。1711819920221)

しかし，一万には，今むでに報告された所謂罪患体質 に承認するにたるるののないてと，およで，放るもの

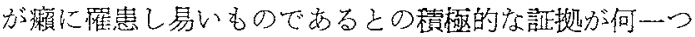
ないことから，癩にかから易い一定の体賢があるという 説は承喼し難いというものも㐫る。221

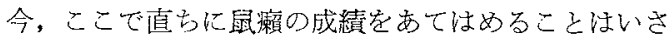
さか飛躍が過ぎるとはい党，こ和を参考として考光るな

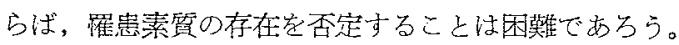

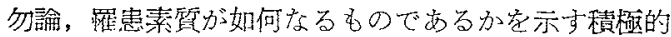

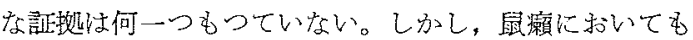
この点では全く同じであって，外観的には何の積極的証 拠はなくとも，病型の発現が先天的素因にもとずくこと は明らかである。このことからみて，人瀨に㧅て，羅 患素質の存在を否定するに恃，逆化，否定するにたる積 極的証明を必要とするのではあるまいか。 
それならば，先天的素因定有するもの，特に Lepromatous 型の素因有主るものは，常にこの型として発 满する遣命にあるのであろらか。

もし，この問題に関して，鼠瀨における実験成績が人 瀨の場合にもあてはまるとするならば，悪性型として発 病すべきマウスの病像が， B C G 予防接種により，良 性型を示すこと艺認㧹た第 5 項の鼠瀨汇対する B C G 免度実験の成續こそ大きな光明ともいうべきものである 50

鼠瀨に対して，BCGがその発症を抑制与る効果のあ ることは Azulay ${ }^{23)}$ ，西村等24)がラットを用いて報告し， 著者225) るマウス完用いて同様な成績を得ている。

しかし，これらの成績はすの゙て接種部に生ずる龙下結 節の大きさにより判定されたものであつて，病型を中心 として，判定することが如何に勝れているが，第 5 項 の㬰験1に示した通りである。

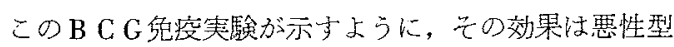
にあら方れるべきすのが，主性型として登症する点に最 も見るべきものがあるのだから，免蚛実験には㤠性型に 発症する、ウス定朋いること名，実験堂成功させる良い 方法の一のといえよう。

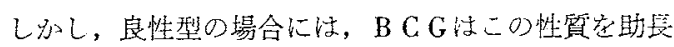
一るに過ざず，また烈性型でも，去の代表の $\mathrm{C}_{3} \mathrm{H}$ 系の 場合には，マウスのもつ抵抗力があまりに微弱なため，

B G G 免疫によつても，た块鼠癞の進展を一時的に抑制

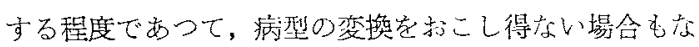
いわけではない。

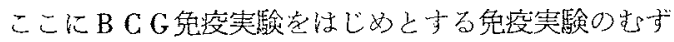
かしさと，黛溶效果の限界があるように思われる。

いずれにせよ，鼠攋に対する B C G の効果注恶性型よ

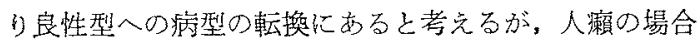
はどうであるうか。

B C G Kよる癩の予防関占る問題は，その効果につ いて目下研究中のものであつて，末犬゙その結諭淂られ ていないが，BCGの效果安認めているもの当浃して少 〈广い。26)27)28\}

この中でも, Fernandez ${ }^{29)}$ のB C G 接㮔者, シベルク リン反心蹋性の未接程者, およびッベルクリン反心㓌性

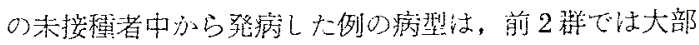
分が Tuberculoid 型大 Lepromatous 型分1例もなか たのに対し，後のツベルタリン反地陰性者群から発病し た場合は，Tuberculoid 型は半数に過ざず，他は，Lepromatous 型か，Indeterminate 群であつたという報告は， 鼠瀨の場合々酸好て良く似ており與味深い。
そこで，BGGによる予防接種の效果性，発泟阻止の 面ばかりでなく、病型の転換という点でもかなりの期待 がかけられるように思われ，この方面に一層の努力が望 まれるものである。

最後に治療の閭題についてふれておきたい。人欟に著

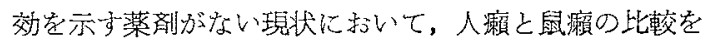
行うことは困䧼であるが, 鼠瀨結節が治瘾におもむく際 は, 㤠性型から食性型への䔟行がみられることは前に述 ベた通りである。このことは, 橮の治療効果があがつた 埸合, 光田反忘が陽転吉ることと考古合せると特に與味 が梁い。鼠瀨の治療実験に沶いて, 病型を中心として観

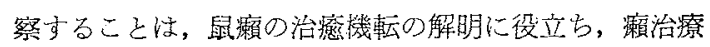
楽の研究にも答与するところがあるものと考える。

鼠瀨と人瀨の関係については與味ある問題も多いが，

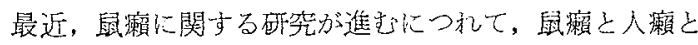
の相違点も数多く指据されるようになつた。その結果， 鼠瀨における成績加ら人攋への類推を行うことに疑問を すつものむあらわ机て来たが，今までに述べてきた成績 から考えて，鼠瀨注，依然，人顆に最も類似した疾患で あり，これに対する研究は，人濑菌による笑験的研究が 不可能な現況に䄧いては, 人癩研究の進歩に少なからず 貢献するものであると信ずる。

特に, 鼠癩の䂙热を, この新しい病型を考慮に入れて 行うならば，さらに一層の進歩が期待出来るのではめる まい心。

\section{結語}

鼠獺菌をマウスに皮下接種した場合，接種部位に生ず る結節の性代少ら，硬い限局性の結節空生ずるものを良 性型, 㜞い濔漫性の結節を生ずるもの昰性型とし, 鼠 转をこの二つの型に大別することを提陧した。

Stefansky の分類が，病型といらょりは，芑しろ病期 をあらわすものであることからみても，新しい病型分類 沙今後大いに検討さるべきものであるう。

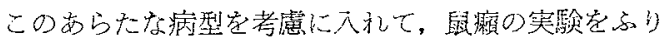
がつてみると，鼠濑の経過，マウスの示主鼠瀨菌に対 する抵抗性, 罪患素質の遗伝, 免疫和よび治寮効果の判 定などに，新らしい多くの知見を加光ることが出来心。

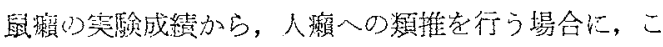

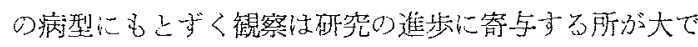
菏ると思故和る。

（終引に, 御指導御校閲它賜つ大工藤教授, 勡物の繁

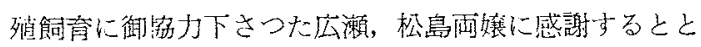


もに, 病理組織標本の検討に種々御教示下さつた瀨研福 士技官に感謝の意を表する。)

\section{文献}

1) 川ロ: レプラ, 26, 318, 1957

2) 川ロ: レプラ, $27,44,1958$

3) 川ロ: レプラ, 27, 49, 1958

4) 川1ロ: レプラ, 27, 423, 1958

5) 川1口: レプラ, $28,43,1959$

6) 川ロ:レプシ, $28,55,1959$

7) 川ロ: レプラ, 28, 59, 1959

8) 川ロ:レプラ, 28, 62, 1959

9) Stefansky, W. K.: Zbl. f. Bakt. Abt. I. Orig., 33, $481 \quad 1903$

10）山本, 佐藤, 佐藤：皮泌程誌，40，184，1936

11）西村: レプラ, 8, 201, 1937

12）戸田：レプラ, 12, 1, 1941

13）占部：レプラ, 18, 39, 1949

14）緒方：第15回日本医学会総会綜合学術集会報告集

$5,7,1959$

15) Webster, L. T.: J. Exp. Med., 57, 793, 1933
I6) Gowen, J. W. \& Schott, R. G.: Am. J. Hygiene, 18, 674, 1933

17) 高島：慶応医学, 19, 1227, 1939

18) Aycock, W. L.: Internat. J. Leprosy, 81371940

19) Keil, E. Zbl. f. Bakt. Abt. I Ref., I34, 5201939

20) 林: レプラ, 11, 120, 1940

21) 林: レプラ, 13, 485, 1942

22）桜茾，西村：大阪医事新誌，13，1143，1942

23) Azulay, R. D.: Internat. J. Leprosy, 22, 61, 1954

24）西村, 柳沢, 野岛，他：レプラ，25，69，1956

25) 川1ロ: レプラ, 24, 64, 1955

26) Montestruc, E. \& Blaché, R.: Rev. Colon. Méd.

Chirur., 15, 358, 1950 Abst. Internat. J. Leprosy, 19, 388, 1951

27) Convit, J., Rassi, E., Canto Rodriguez, F. \& Contreras, R.: Internat. J. Leprosy, 20, 347, 1952

28) Souza Campos, N.: Internat. J. Leprosy, 21, 307, 1953

29) Fernandez, J. M. M. : Internat. J. Leprosy, 23 ,243, 1955 
PLATE

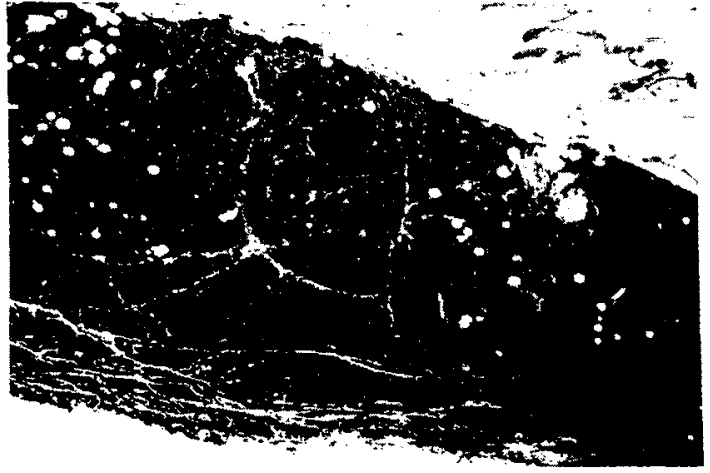

Fig. 1 C3H, subcutaneous leproma. 12 wks. (Ziehl-Haematoxylin stain $\times 40$ )

Muri-lepra cells (dark part) constitute most of the muri-leproma, and except for formation of capillary and lymph vessels, inflammatory findings are almost absent. Skin is visible on upper right.

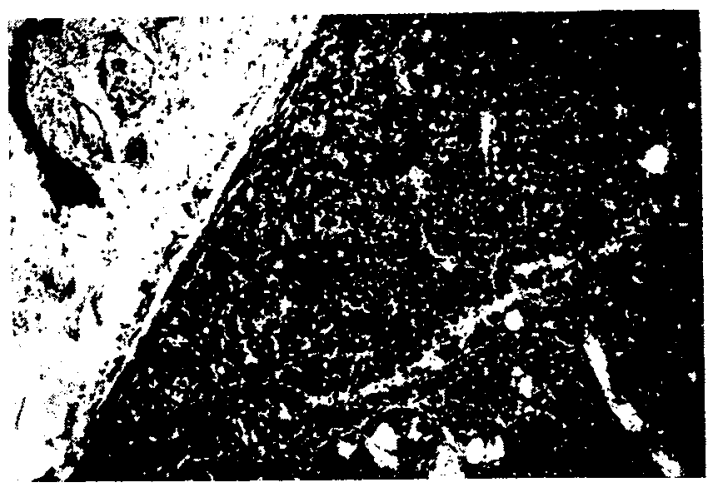

Fig. 3 C3H, -do- 12w. (Z.H $\times 100)$ Fig. I slightly magnified. Cellular infitration is not seen between the skin on the left side and the muri-leproma, the muri-lepra cells in the periphery of muri-leproma being spindle-shaped, the other parts being filled with round-shaped muri-lepra cells. It is a typical symbiotic phase.

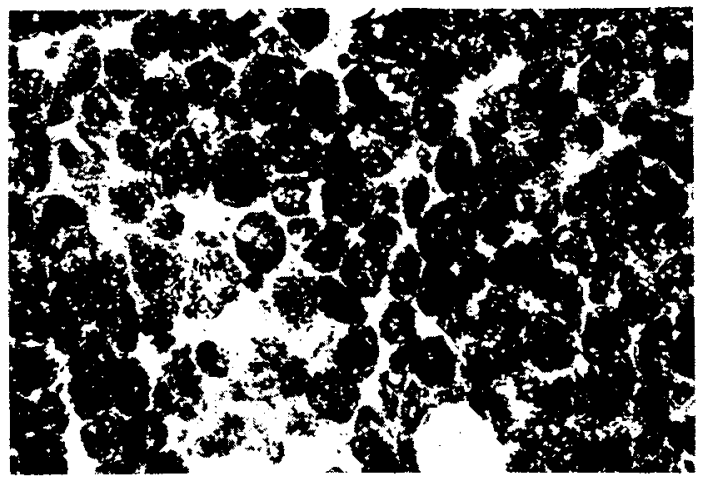

Fig. 5 C3H, -do- 12w. (Z-H $\times 400)$ Fig. 3 highly magnified. Rod-shaped muri-lepra bacilli fill the protoplasm of the murilepra cells which are swollen in a round shape.

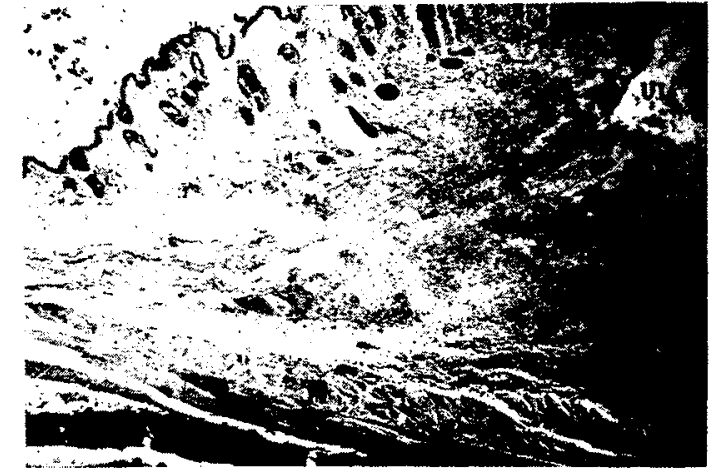

Fig. 2 C57BL/6, subcutaneous leproma. I2w. (Z-H $\times 40)$ Epidermis and hair follicle can be seen in upper left. UL: ulcer in skin. $\uparrow$ : group of muri-lepra cells in periphery of ulcer and is surrounded by granulomas (granulomatous phase) composed of epithelioid cells, collagenous fibre and lymphocyteinfiltration which extend to muscular layer (M). Marked diffe. rence from Fig. I.

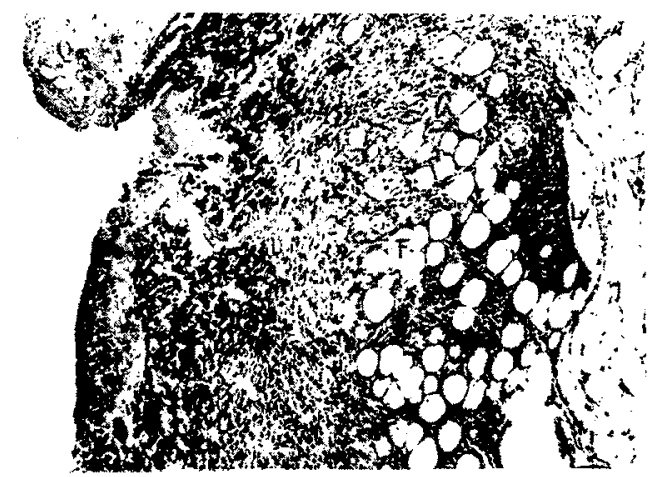

Fig. 4 C57BL $/ 6$, -do. 12 w. ( $\mathrm{C} \cdot \mathrm{H} \times 100)$

Left are necrosis and demarcation-layers of the ulcer. Second layer $(\hat{)}$ ) is muri-lepra cell layer. Third layer is epithelioidal cell layer. Fourth layer (Ly) is strong lymphocytic infiltration. $F$ : subcutaneous fatty cells.

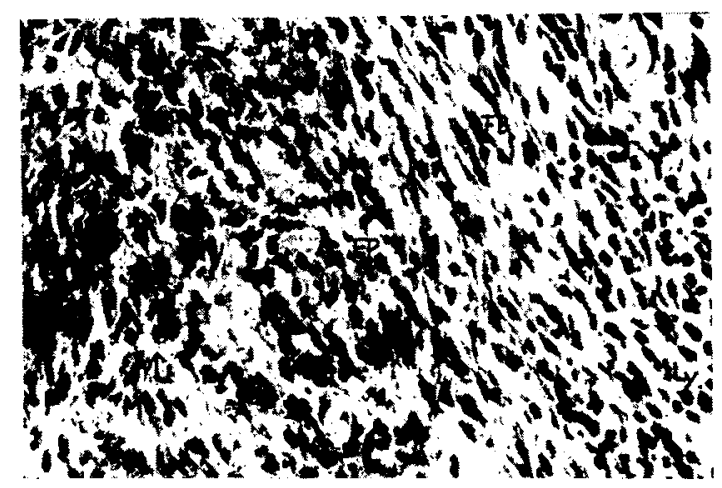

Fig. $6 \quad \mathrm{Cs} / \mathrm{BL} / 6,-$ do $-12 \mathrm{w} .(\mathrm{Z}-\mathrm{H} \times 400)$

$\uparrow$ ML: Muri-lepra cells. Ep: Epithelioid cells. FB: Fibro blasts. Ly: Lymphglands. Transfer to epithelioid cells from star- $\sim$ spindle-shaped cells moderately $\sim$ slightly phagocytizing rodshaped muri-lepra bacilli, multiplication of fibroblasts and lympho. cyte-infiltration can be seen. Symbiotic phase $\rightarrow$ Granulomatous phase. 


\section{PLATE II}

The Leproma in Benign Type of Mouse Leprosy

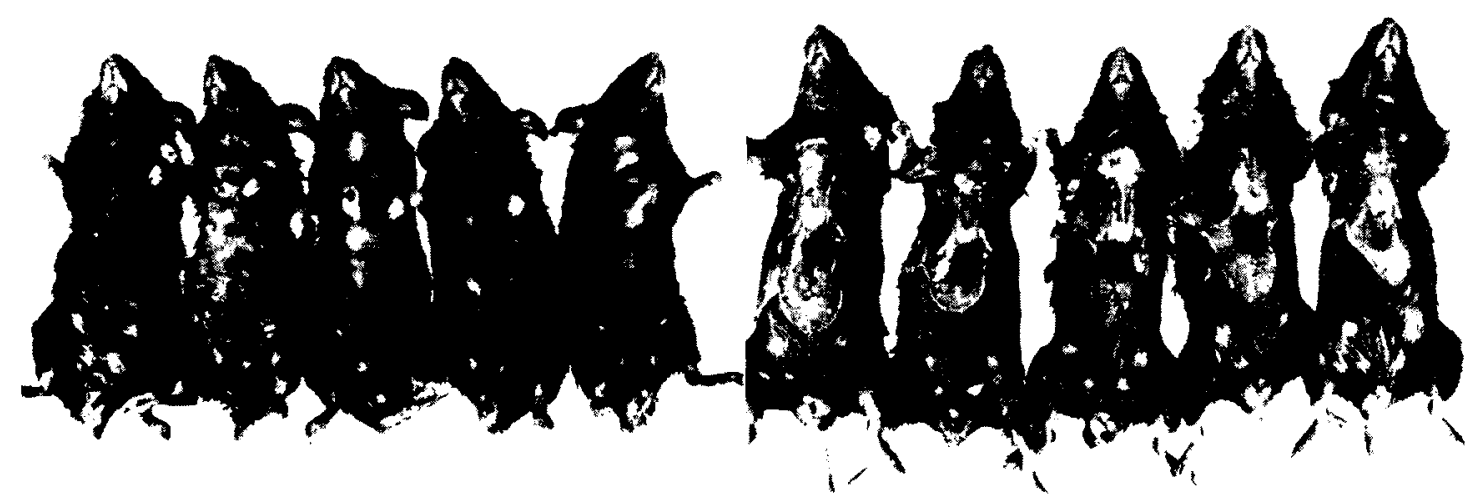

(C57BL/6)

The Leproma in Malignant Type of Mouse Leprosy
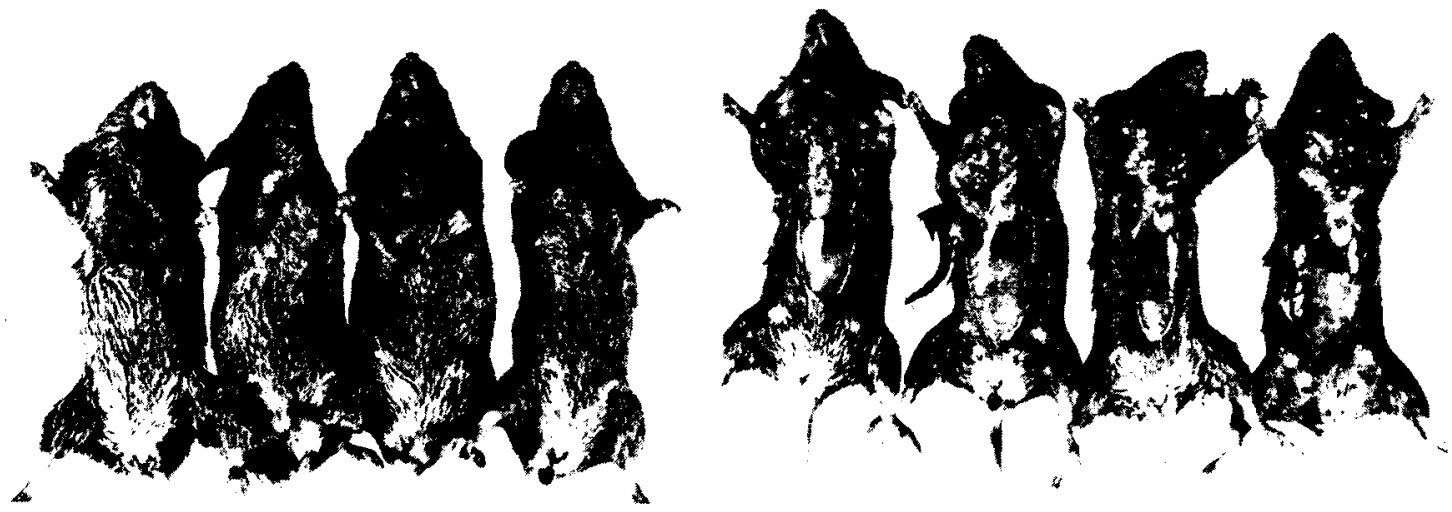

$(\mathrm{C} 3 \mathrm{H})$ 